https://doi.org/10.52340/lac.2021.672

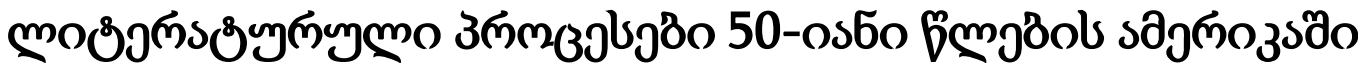

\author{
6s6s zszons

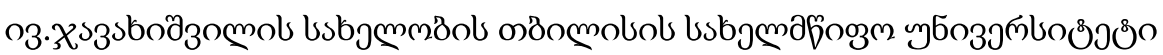 \\ e-mail:nanagagua95@yahoo.com
}

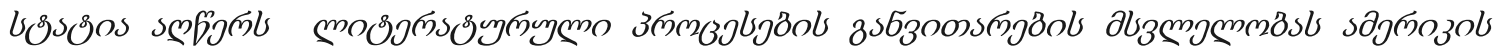

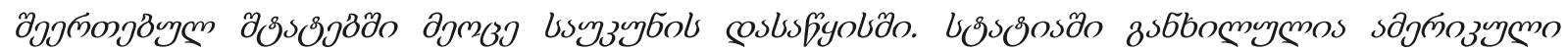

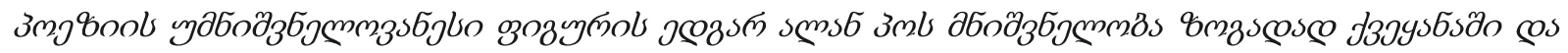

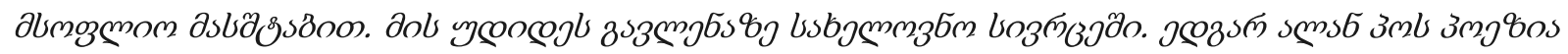

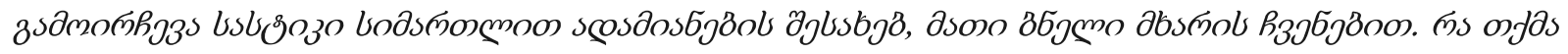

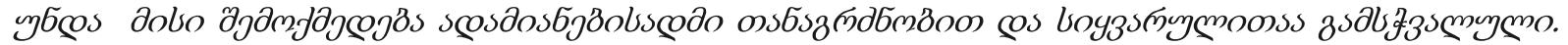

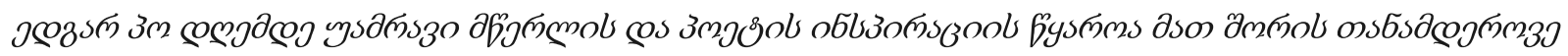

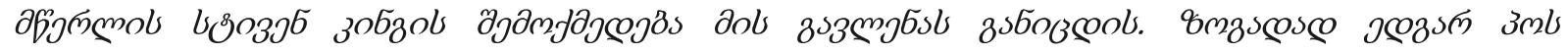

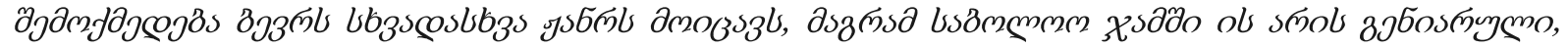

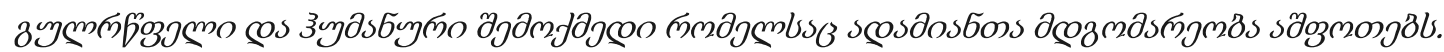

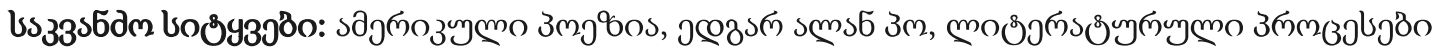

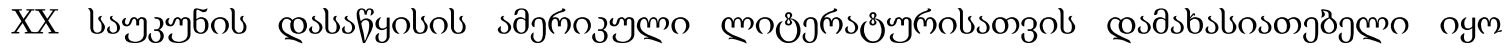

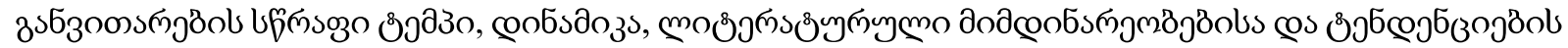

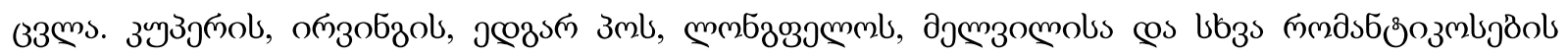

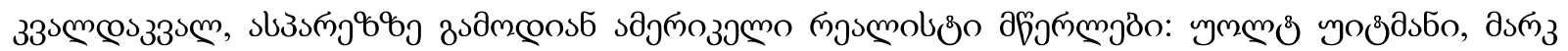

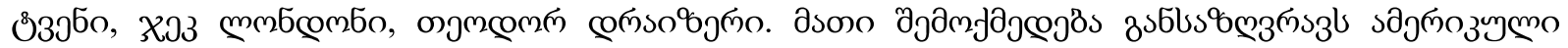

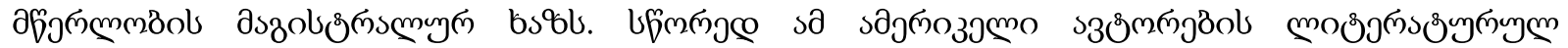

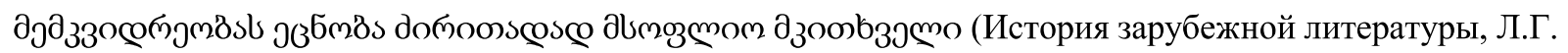

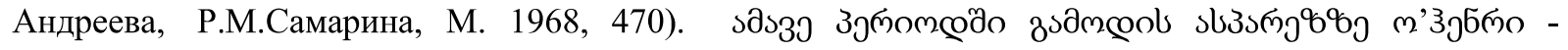




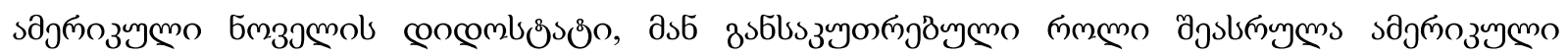

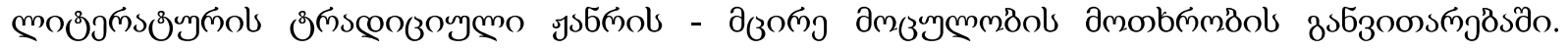

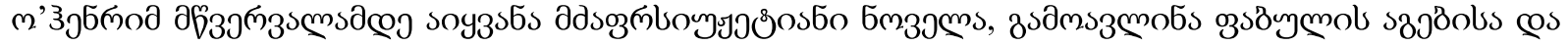

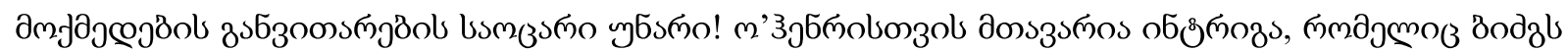

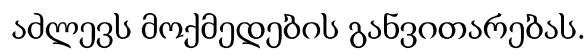

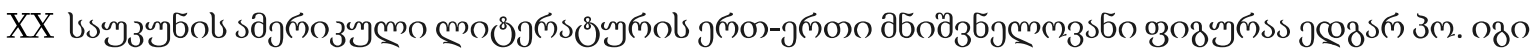

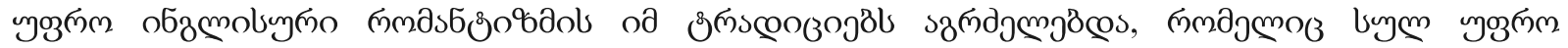

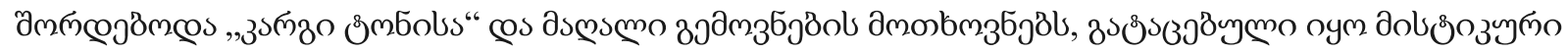

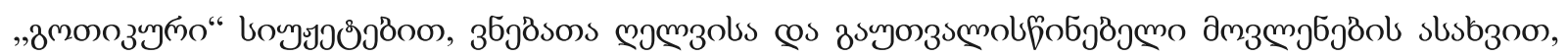

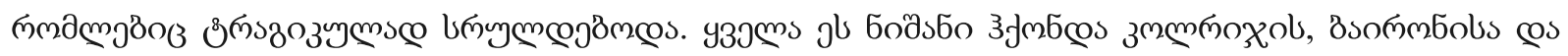

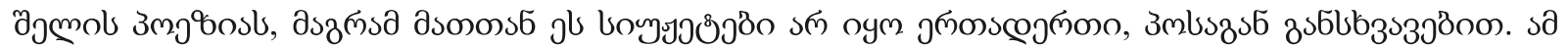

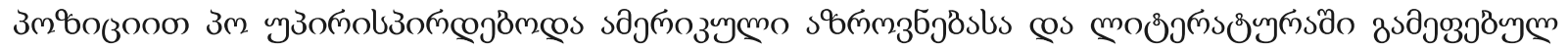

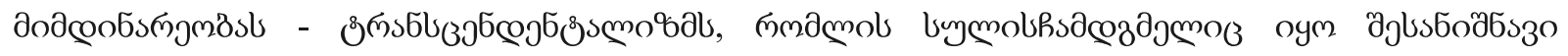

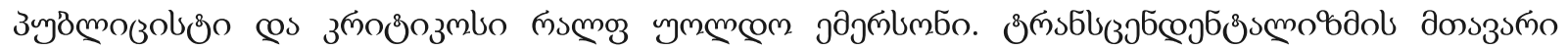

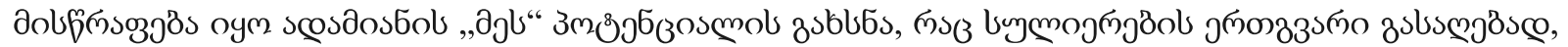

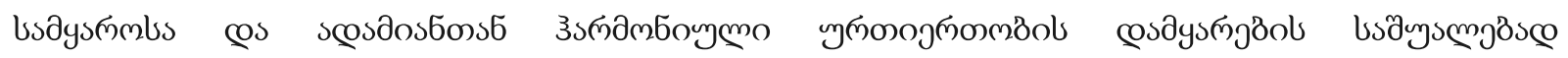

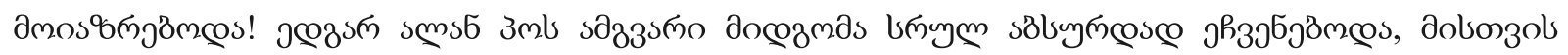

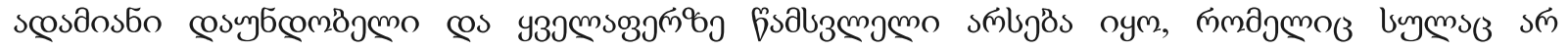

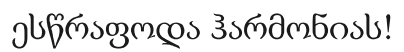

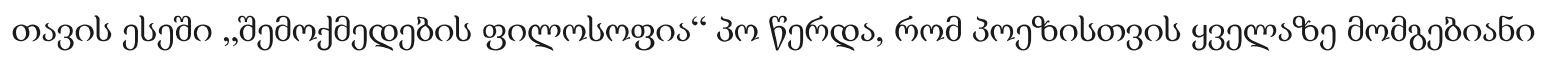

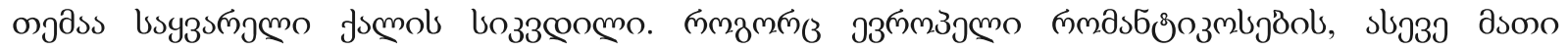

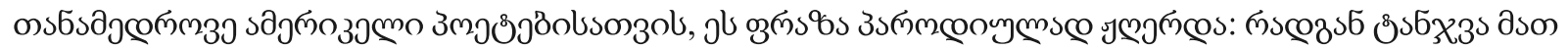

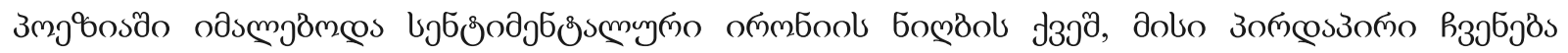

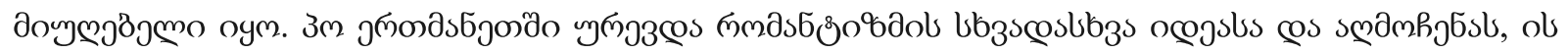

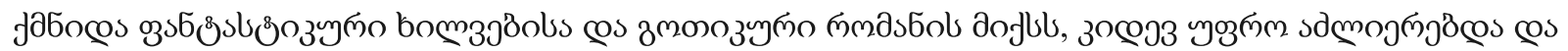

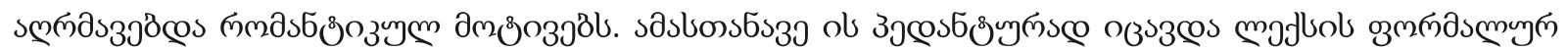

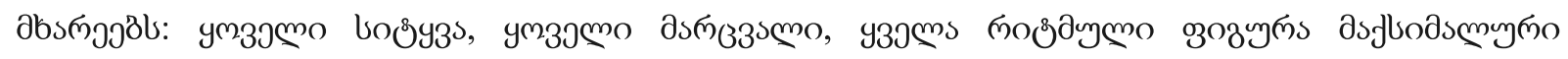

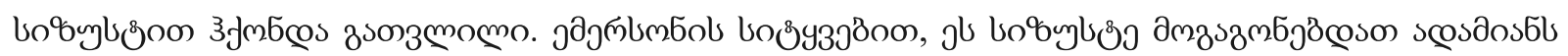

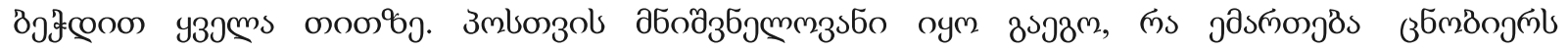

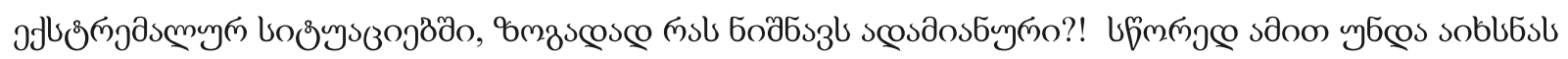

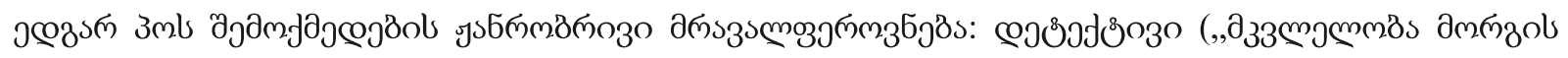

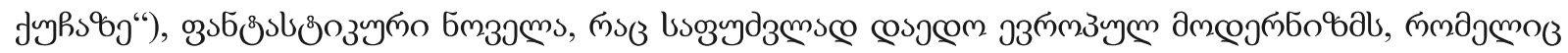




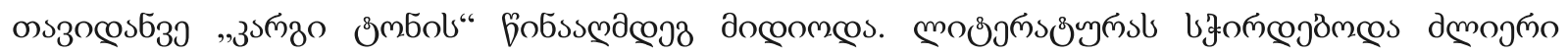

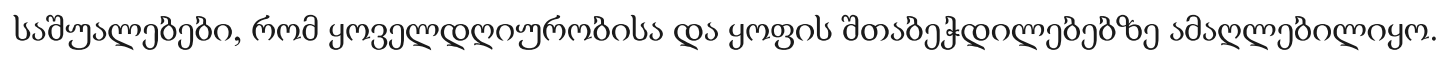

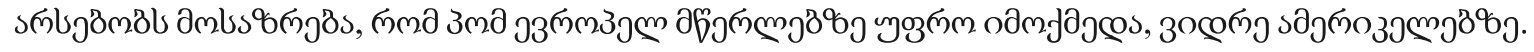

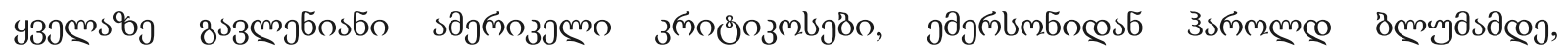

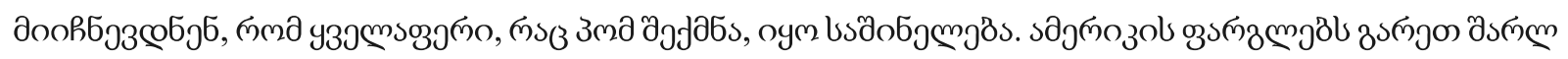

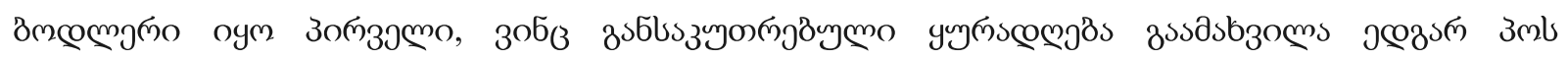

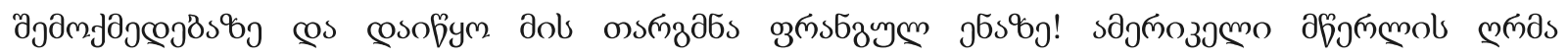

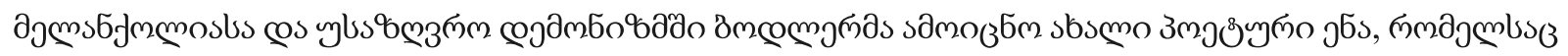

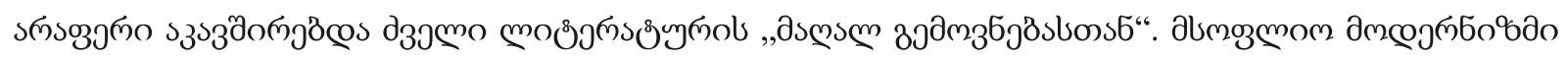

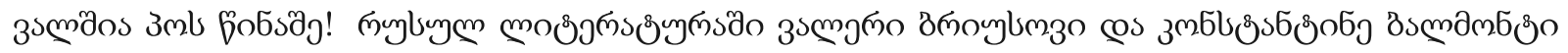

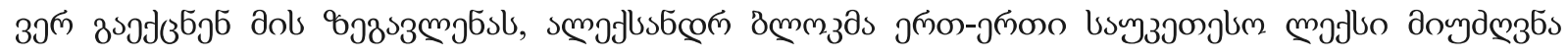

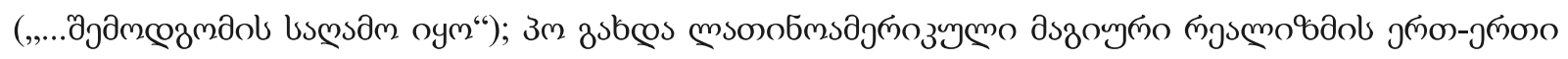

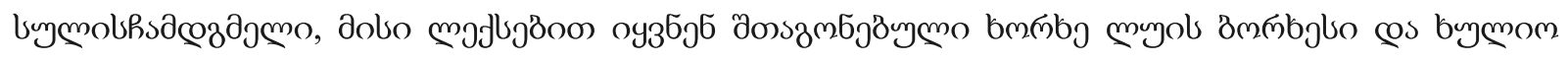

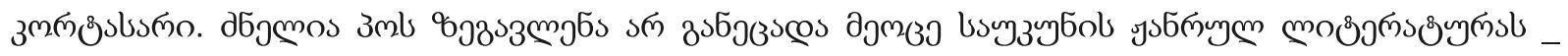

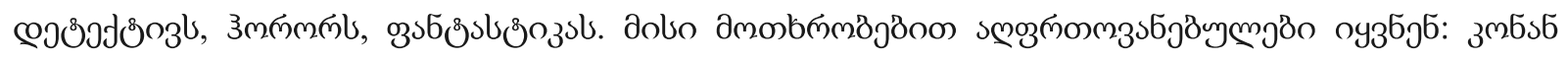

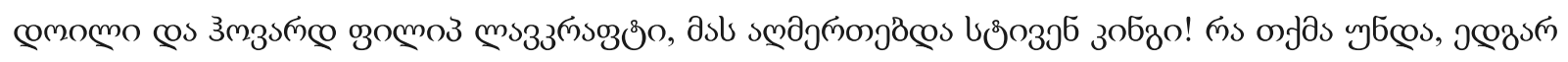

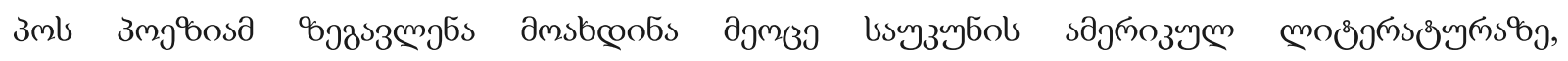

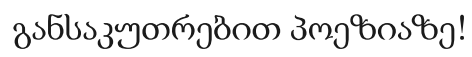

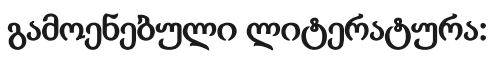

1. Dickle Margaret, Sylvia Plath's Narrative Strategies by The Iowa Review.

2. Hardwick Elisabeth, On Sylvia Plath. The New York Book Review. 1971, Aug.12

3. Libby Anthony, God's Lioness and the Priest of Sycorax: Plath and Hughes. University of Wisconsin Press/ Journals Division.

4. Plath Sylvia, The Colossus and other poems, Vintage International. New York.

5. Plath Sylvia, Letters home, Correspondence 1950-1963, selected and edited with commentary by Auralia Schober Plath. HarperParennial. 1992

6. Rosenblatt Jon, Sylvia Plath: The Drama of Initiation, Duke University Press, 1975 Spring issue.

7. Stevenson Anne,Bitter Fame. Houghton Mifflin Company. Boston 1989.

8. Wagner, W. Linda, Critical Essays on Sylvia Plath. G.K.Hall \& Company. Boston.

9. /https://arzamas.academy/materials/1605/

10. (История зарубежной литературы, Л.Г. Андреева, Р.М.Самарина, М. 1968, 470). 


\title{
Nana Gagua
}

\section{Literary Processes In America in the 50s of the XXth Century}

\author{
Iv.Javakhishvili Tbilisi State University
}

\begin{abstract}
Above mentioned article describes development of literary process in the United States at the beginning of the $20^{\text {th }}$ century. The article discusses the most influential figure of American Poetry Edgar Allan Poe. His immersive influence on art field. Generally his poetry is distinguished with expressing bitter truth about dark side of human nature. His works definitely express sympathy and love toward humans. Edgar Allen Poe is an inspiration for many modern writers, among them is Steven King. Generally Edgar Allen Poe's works contain different genres, in the end he is genius, honest and human artist who worries about human's condition.
\end{abstract}

Key words: American poetry, Edgar Allan Poe, literary processes

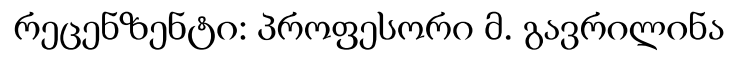

